Inga A. Zasada

USDA-ARS Nematology Laboratory, Beltsville, MD

Felicitas Avendano

lowa State University, Ames, IA

Yuncong C. Li

University of Florida

Tropical Research and Education Center, Homestead, FL
Terry Logan

Logan Environmental Inc., Beaufort, SC

Haddish Melakeberhan

Michigan State University, East Lansing, MI

Stephen R. Koenning

North Carolina State University, Raleigh, NC

Greg L. Tylka

Iowa State University, Ames, IA

\title{
Potential of an Alkaline-Stabilized Biosolid to Manage Nematodes: Case Studies on Soybean Cyst and Root-Knot Nematodes
}

The use of treated biosolids for pest management and soil nutrient augmentation is not a new practice, but it has increased in the last two decades, primarily in the United States (22). In the late 1970s, the first land application regulations were formulated by the U.S. Environmental Protection Agency (USEPA) in response to the Clean Water Act (44). Land application of sewage sludge for soil amendment and land reclamation has increased over time as a result of the ban on ocean dumping of wastewater residuals (Ocean Disposal Ban Act of 1988). The Act also minimizes other disposal options, such as land-filling or incineration. In 1993, the Standards for the Use or Disposal of Sewage Sludge (Code of Federal Regulations Title 40, Part 503) was created $(45,46)$. Part 503 (as it is commonly called) set pollutant limits, operational standards for human/animal pathogen and vector-attraction reduction, management practices, and other provisions intended to protect public health and the environment from any reasonably anticipated adverse effects from chemical pollutants and pathogenic organisms. In 1995, the EPA promoted the terminology "biosolids" rather than "sewage sludge" and defined biosolids as "the primarily organic solid product yielded by municipal wastewater treatment processes that can be beneficially recycled as soil amendments and meets the standards of Part 503". Although the term is sometimes controversial

Corresponding author: Inga A. Zasada E-mail: Inga.Zasada@ars.usda.gov

\section{doi:10.1094/PDIS-92-1-0004}

This article is in the public domain and not copyrightable. It may be freely reprinted with customary crediting of the source. The American Phytopathological Society, 2008.
(33), we will use biosolid in reference to the product tested in this research.

In 1998, approximately 6.9 million dry tons of biosolids were disposed of in the United States, of which $41 \%$ was used for land application (Table 1) (47) on less than $1 \%$ of the nation's agricultural land. A state-by-state summary of biosolid production and use for 2000 is available (11). Biosolid production is expected to increase to 8.2 million dry tons in 2010-an approximately $20 \%$ increase in just over 10 years (47). An increase in the proportion that is land-applied is also expected (Table $1)$.

Plant-parasitic nematodes cause nearly $\$ 10$ billion in crop losses per year in the United States and about $\$ 100$ billion globally $(17,37)$. Nematodes are responsible for reductions in yield and quality over a broad range of hosts. Strategies used to control plant-parasitic nematodes include the use of nematicides, resistant varieties, nonhost rotations, cover crops, cultural practices, and biological control. Because approximately $48 \%$ of biosolids will be land-applied in 2010 (Table 1), the effects of such application, alone or in combination with other management practices, required study. In 2001, the U.S. Congress mandated that research be conducted on an alkaline-stabilized biosolid product (NViro Soil [NVS]) and the potential for this product to control plant-parasitic nematodes. The ensuing collaborative research effort included federal (U.S. Department of Agriculture-Agricultural Research Service), university (Iowa State University, Ohio State University, Michigan State University, North Carolina State University, and University of Florida), and private (N-Viro International, Toledo, $\mathrm{OH}$ ) organizations. Numerous laboratory, greenhouse, and field experiments were conducted. In this paper, we summarize these studies and discuss the opportunities and challenges presented by using alkaline-stabilized biosolids for plant-parasitic nematode management.

\section{Past Experiences with Biosolids for Nematode Management}

Decreases in population densities of plant-parasitic nematodes by raw and composted sewage sludge were demonstrated in the 1970s (12). Raw sewage sludge reduced Meloidogyne incognita (the southern root-knot nematode) juvenile penetration, galling, and egg production on tomato roots in greenhouse pots (7). Although soil amended with heat-treated sewage sludge, alone and combined with yard waste, had few consistent effects on plant-parasitic nematodes, it reduced final $M$. incognita population densities on squash (23). Amendment of field soil with dried, pelletized biosolids increased $M$. incognita population densities and root galling on tomato compared with the nontreated control (24). More recently (2), composted sewage sludge suppressed Meloidogyne javanica (the Javanese root-knot nematode) on tomato, when applied at very high rates (greater than $75 \% \mathrm{wt} / \mathrm{wt}$ ). Although results were inconsistent among studies, they indicated a potential for biosolids as a plant-parasitic nematode management tactic.

Prior to initiation of the research effort discussed herein, an alkaline-stabilized biosolid (NVS) applied for nutrient management purposes was observed to reduce population densities of Heterodera glycines (the soybean cyst nematode) in Ohio (T. Logan, unpublished data). The reduction was sustained for 3 years in some fields and enabled the farmer to insert soybeans into a crop rotation cycle 2 to 3 
years earlier than in a nonhost crop rotation cycle. Similar results were reported from Canada (49), where 2 to 20 dry t/ha NVS suppressed $H$. glycines.

\section{The N-Viro Biosolids}

\section{Alkaline Stabilization Process}

Since the advent of advanced wastewater treatment in the late 1960s in the United States, much attention has been given to treatment and disposal or utilization of the residual organics. Prior to the 1980s, most biosolids were biologically digested to stabilize the residual organics and to kill some pathogens. In the 1980s, more advanced technologies for biosolids treatment emerged to produce a pathogenfree product and stabilize residual organics. The two most widely used approaches are biological composting and alkaline stabilization (47). Whereas composting relies on biological degradation, heat, and drying to kill pathogens and stabilize organic matter, alkaline stabilization involves a combination of high $\mathrm{pH}$, heat, and drying to achieve the same purpose. Two classes of biosolids can be produced, classes A and B. Class A biosolids contain no detectable levels of pathogens, meet strict vector attraction reduction requirements, and have low levels of metals. Class B biosolids are treated but still contain detectable levels of pathogens. Whereas class A biosolids can be applied without restrictions, class $\mathrm{B}$ biosolids incur land buffer requirements and crop harvesting restrictions (45).

One alkaline stabilization approach that yields a class A product is the N-Viro process (Fig. 1). The basis of the N-Viro process $(6,21)$ is to destroy pathogens through a combination of the following stresses: (i) alkaline $\mathrm{pH}$; (ii) accelerated drying; (iii) high temperature; (iv) high ammonia $\left(\mathrm{NH}_{3}\right)$; (v) salts; and (vi) indigenous microflora. These stresses are produced in the biosolid when alkaline admixtures (AA) with varying unique properties are added. A number of industrial waste alkaline materials are used alone or together as the AA in the N-Viro process. These include cement kiln dust (CKD), lime kiln dust (LKD), wood ash, various coal combustion ashes that include flue gas desulfurization byproduct (FGD), or alkaline fly ash. If the AA contains enough free lime (calcium oxide $[\mathrm{CaO}]$, calcium hydroxide $\left[\mathrm{Ca}(\mathrm{OH})_{2}\right]$, or other strong alkali) to give a $\mathrm{pH}$ rise to greater than 12.0 and an exothermic reaction necessary to achieve desired temperatures $\left(52\right.$ to $\left.62^{\circ} \mathrm{C}\right)$, no other additive is needed. Calcium oxide is added to supplement the free lime content of the AA if it is not "hot" enough.

Raw primary biosolids, either waste-activated or digested, with solids content of 18 to $40 \%$ can be treated (Fig. 1). Biosolids and AA are mixed with a pug mill or screw blender. The ratio of AA to biosolids varies with the solids content, with a higher ratio used for those biosolids with lower solids content. In general, the AA dose ranges from 25 to $50 \%$ of the dewatered biosolids wet weight. With proper mixing speeds, the resultant product is a granular, easy-to-handle soil-like material that is further processed by air drying or heating.

A similar N-Viro process, which differs in that it does not use heat, can be employed to treat animal manures. Alkaline

Table 1. Past and projected biosolid use and disposal in the United States (47)

\begin{tabular}{|c|c|c|c|c|c|c|c|c|c|}
\hline \multirow[b]{2}{*}{ Year } & \multirow[b]{2}{*}{$\begin{array}{c}\text { Biosolid generation } \\
\text { (dry tons) }\end{array}$} & \multicolumn{4}{|c|}{ Beneficial use } & \multicolumn{4}{|c|}{ Disposal } \\
\hline & & $\begin{array}{c}\text { Land } \\
\text { application }\end{array}$ & $\begin{array}{l}\text { Advanced } \\
\text { treatment }\end{array}$ & $\begin{array}{c}\text { Other } \\
\text { beneficial use }\end{array}$ & Total & $\begin{array}{l}\text { Surface disposal/ } \\
\text { landfill }\end{array}$ & Incineration & Other & Total \\
\hline 2000 & 7.1 & $43 \%$ & $12.5 \%$ & $7.5 \%$ & $63 \%$ & $14 \%$ & $22 \%$ & $1 \%$ & $37 \%$ \\
\hline 2005 & 7.6 & $45 \%$ & $13 \%$ & $8 \%$ & $66 \%$ & $13 \%$ & $20 \%$ & $1 \%$ & $34 \%$ \\
\hline 2010 & 8.2 & $48 \%$ & $13.5 \%$ & $8.5 \%$ & $70 \%$ & $10 \%$ & $19 \%$ & $1 \%$ & $30 \%$ \\
\hline
\end{tabular}

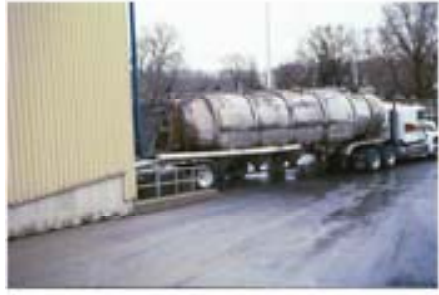

Dewatered biosolids

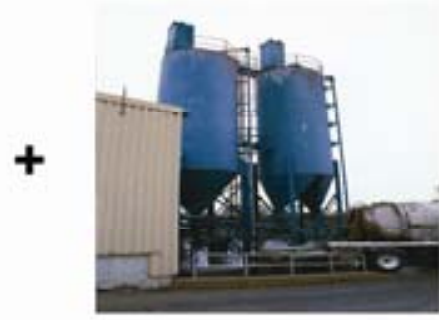

Alkaline admixture

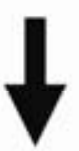

(i.e.: fly ash, cement kiln dust)

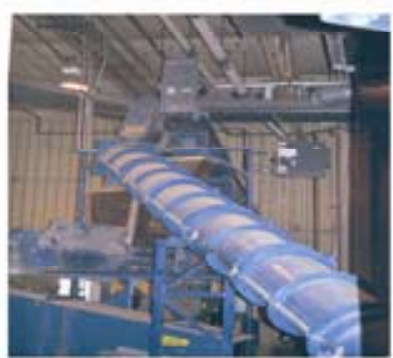

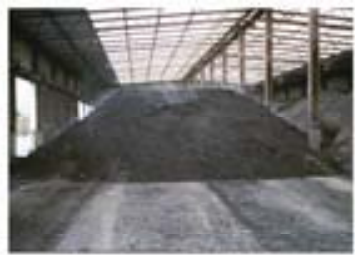

Curing requirements:

$52-62{ }^{\circ} \mathrm{C}$

$\mathrm{pH}$ level $>12$ $50 \%$ solids

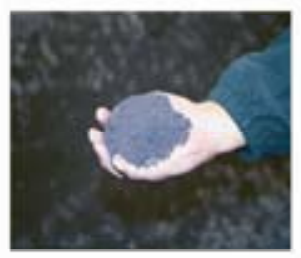

Final Product $\mathrm{N}$-Viro Soil

Fig. 1. The N-Viro alkaline stabilization process (photos courtesy of David Chitwood, USDA-ARS, with permission from N-Viro International, Toledo, $\mathrm{OH}$ ). 
Table 2. Typical chemical characteristics of N-Viro Soil produced in Toledo, $\mathrm{OH}$ (N-Viro International) expressed on a percent dry weight or $\mathrm{mg} / \mathrm{kg}$ basis $^{\mathrm{a}}$

\begin{tabular}{lc}
\hline Chemical properties & \\
\hline $\mathrm{pH}$ & 12.2 \\
Nitrogen (\%) & 1 \\
Phosphorus (\%) & $0.2-1.1$ \\
Potassium (\%) & 1 \\
Sulfur $(\%)$ & 5 \\
Calcium (\%) & $10-40$ \\
Magnesium $(\%)$ & 1 \\
Sodium $(\%)$ & $<0.2$ \\
Arsenic $(\mathrm{mg} / \mathrm{kg})$ & 27.4 \\
Cadmium $(\mathrm{mg} / \mathrm{kg})$ & $<1.4$ \\
Chromium $(\mathrm{mg} / \mathrm{kg})$ & 65.4 \\
Copper $(\mathrm{mg} / \mathrm{kg})$ & 74.0 \\
Lead $(\mathrm{mg} / \mathrm{kg})$ & 28.4 \\
Mercury $(\mathrm{mg} / \mathrm{kg})$ & $<0.7$ \\
Molybdenum $(\mathrm{mg} / \mathrm{kg})$ & 9.2 \\
Nickel $(\mathrm{mg} / \mathrm{kg})$ & 61.1 \\
Selenium $(\mathrm{mg} / \mathrm{kg})$ & 8.5 \\
Zinc $(\mathrm{mg} / \mathrm{kg})$ & 188 \\
\hline
\end{tabular}

${ }^{a}$ Elemental composition and characteristics vary depending upon manufacturing location.

materials are added to raise $\mathrm{pH}$ above 10.0. Disinfection of the manure is achieved primarily by the high levels of gaseous $\mathrm{NH}_{3}$ contributed by the manure at this $\mathrm{pH}$.

\section{Properties of N-Viro Soil}

The strong alkalinity in NVS is responsible for its high $\mathrm{pH}$ (Table 2), but the $\mathrm{pH}$ of NVS when added to soil is very different than that of the material itself. When NVS is added to soil, an initial neutralization reaction (Fig. 2A) occurs quickly due to the high reactivity of the $\mathrm{Ca}(\mathrm{OH})_{2}$ component compared with the $\mathrm{CaCO}_{3}$ component. This reaction is very rapid and is followed by acid neutralization which occurs by calcite dissolution (Fig. 2B); this is the reaction that occurs in soil when limestone is added. It is important to understand the balance between these two reactions when applying NVS for plantparasitic nematode suppression.

The typical chemical characteristics of NVS are given in Table 2 . The chemistry of NVS is dominated by calcium (Ca); about $20 \%$ of the $\mathrm{Ca}$ in NVS is watersoluble. Soluble salts are high in NVS as they are in biosolid composts or heat-dried biosolids, because these processes involve the evaporation of water and concentration of salts from the biosolids. The total carbon content of NVS is about half that of digested biosolids, the difference due to the added mineral AA. The nitrogen $(\mathrm{N})$ in NVS exists almost entirely as organic $\mathrm{N}$ because the high $\mathrm{pH}$ drives off free ammonia $\left(\mathrm{NH}_{3}\right)$ from the biosolids. All of the phosphorus is contributed by the biosolids and probably exists in NVS as a combination of organic phosphorus $(\mathrm{P})$ and calcium phosphates. Potassium content of NVS varies widely, and is con-

\section{A. $\mathrm{Ca}(\mathrm{OH})_{2}+2 \mathrm{H}^{+}=\mathrm{Ca}^{2+}+2 \mathrm{H}_{2} \mathrm{O}$ \\ B. $\mathrm{CaCO}_{3}+\mathrm{H}^{+}=\mathrm{Ca}^{2+}+\mathrm{HCO}_{3}^{-}$ \\ C. $\mathrm{NH}_{4}^{+}+\mathrm{OH}^{-} \stackrel{\mathrm{pK}_{\mathrm{a}}=9.25}{\longleftrightarrow} \mathrm{NH}_{3}+\mathrm{H}_{2} \mathrm{O}$}

Fig. 2. Important chemical reactions to understand when utilizing alkaline stabilized biosolids to control plant-parasitic nematodes. A, initial acid neutralization, B, calcite dissolution, and $\mathrm{C}$, Henderson-Hasselbalch equation.

tributed by $\mathrm{CKD}$, which can contain as much as 5 to $7 \% \mathrm{~K}$. Most of the sulfur in NVS is in the form of gypsum from the fly ash in the AA; a lesser amount is contributed by sulfur-containing proteins in biosolids. Trace element contents of NVS are low compared with that of U.S. biosolids (Table 2 ).

\section{Traditional Uses of $\mathrm{N}$-Viro Soil}

$\mathrm{N}$-Viro Soils are currently produced in more than 30 locations in the United States, United Kingdom, Israel, and Brazil (www.nviro.com). Existing markets or markets undergoing developmental research include those for agricultural limestone substitutes/low analysis fertilizers, land reclamation, soil amendments/urban soils, soil blend ingredients, and landfill cover materials. Agricultural limestone substitute/low analysis fertilizer is the most developed NVS market, particularly in Ohio, New York, Florida, Indiana, and North Carolina. As a limestone substitute, NVS is typically applied at a rate of 10 t/ha dry weight every 2 to 4 years, depending on location. The objective of the research presented here was to explore another possible market for the utilization of NVS, thereby increasing the value-added benefit of the product. A summary of our research efforts in Florida, Iowa, Maryland, Michigan, and North Carolina is compiled in Table 3.

\section{Effects of N-Viro Soil on Soybean Cyst Nematode}

$H$. glycines, the soybean cyst nematode (Fig. 3A and B), causes greater yield reduction in soybean (Glycine max) than any other pathogen or pest in the United States (51). It is widely spread throughout the soybean growing regions of the United States and elsewhere, causing yield losses of up to $50 \%$. Current management practices include crop rotation with nonhosts and resistant soybean cultivars. However, the sources of resistance to $H$. glycines are limited, and overuse of resistant soybean cultivars may impose a strong selection pressure on the nematode population, resulting in the resistant cultivars' becoming ineffective $(15,29)$. Alternative management options have been suggested to sup- plement the use of resistant soybean cultivars, one of which is the application of soil amendments such as NVS. NVS was evaluated in field, microplot, and greenhouse experiments in Iowa, Michigan, and North Carolina for $H$. glycines management.

Research at Iowa State University (G. L. Tylka and F. Avendano, unpublished data) examined the effect of NVS on $\mathrm{H}$. glycines populations and on soybean yield under field conditions (Table 3). Experiments were conducted at different locations in central Iowa from 2002 to 2006; the soil types of experimental plots were either a Hanlon fine sandy loam or a Harps loam. Soybean cultivars, resistant or susceptible to $H$. glycines, were planted in replicated plots. Treatments were fallow, NVS at 6 and 17 dry t/ha, and a nontreated control. In 2005 and 2006, two application methods, broadcast and banded (Fig. 4A and B), were also tested. NVS was incorporated into the soil immediately after application in all cases. Data collected each year consisted of $H$. glycines egg population densities at planting and at harvest, soil $\mathrm{pH}$ at planting and at harvest, and soybean yield. In addition, soil $\mathrm{pH}$ and $H$. glycines population density were measured 30 days after application of NVS in 2005, and soil $\mathrm{pH}$ was measured in soil samples collected 2 days after application in 2006. Results were fairly consistent from year to year; there were no statistically significant differences in $H$. glycines population density, soybean yield, or changes in soil $\mathrm{pH}$ across treatments. Soil $\mathrm{pH}$ after NVS amendment varied from 6.5 to 7.5 .

In North Carolina (16), field experiments were conducted during 2003 and 2004 on a Woodington sand $(87 \%$ sand, $11 \%$ silt, $2 \%$ clay, $<1 \%$ organic matter) naturally infested with $H$. glycines (Table 3 ). NVS at rates of $0,7,13$, and 20 dry t/ha was broadcast-applied, and soybean was planted immediately after application. The experiment was a split-plot design with main plots of either $H$. glycines-resistant or -susceptible cultivars and split plots of the four rates of NVS. Data collected consisted of preplant soil samples to determine population densities of juveniles, midseason plant samples for cyst population 
Table 3. Summary of results of experiments evaluating N-Viro Soil (NVS) for plant-parasitic nematode management conducted in multiple states from 2002 to 2006

\begin{tabular}{|c|c|c|c|c|c|c|}
\hline Location & $\begin{array}{l}\text { N-Viro Soil } \\
\text { (dry t/ha) }\end{array}$ & $\begin{array}{l}\text { Nematode } \\
\text { tested }\end{array}$ & $\begin{array}{l}\text { Experiment } \\
\text { type }\end{array}$ & $\begin{array}{l}\text { Application } \\
\text { method }\end{array}$ & Soil & Description of response \\
\hline IA & 6 and 17 & $\begin{array}{l}\text { Heterodera } \\
\text { glycines }\end{array}$ & Field & Incorporated & $\begin{array}{l}\text { Sandy loam } \\
\text { to loam }\end{array}$ & $\begin{array}{l}\text { No reduction in } H \text {. glycines population } \\
\text { densities at either rate. }\end{array}$ \\
\hline $\mathrm{NC}$ & $7,13,20$ & H. glycines & Field & Broadcast & Sand $(87 \%)$ & $\begin{array}{l}\text { Nonsignificant increase in } H \text {. glycines } \\
\text { population densities and yield increase in } \\
H . \text { glycines-resistant cultivars with increasing } \\
\text { rates of NVS. }\end{array}$ \\
\hline $\mathrm{NC}$ & $7,13,20$ & H. glycines & Microplot & Broadcast & Sand $(91 \%)$ & $\begin{array}{l}\text { Increase in } H . \text { glycines population densities } \\
\text { with increasing rates of NVS. }\end{array}$ \\
\hline $\mathrm{NC}$ & $13,27,40$ & H. glycines & Field & Incorporated & Sand $(91 \%)$ & $\begin{array}{l}\text { Nonsignificant decrease in } H \text {. glycines } \\
\text { population densities with increasing rates of } \\
\text { NVS. Increase in } H \text {. glycines-resistant } \\
\text { soybean with increasing rates of NVS }\end{array}$ \\
\hline MI & 10 and 40 & H. glycines & Greenhouse & Incorporated & Sandy loam & $\begin{array}{l}\text { Numbers of preadult stages and cysts generally } \\
\text { decreased with increasing rates of NVS. }\end{array}$ \\
\hline $\mathrm{NC}$ & $7,13,20$ & $\begin{array}{l}\text { Meloidogyne } \\
\text { incognita }\end{array}$ & Microplot & Broadcast & Sand $(91 \%)$ & $\begin{array}{l}\text { Reduction in midseason } M \text {. incognita juvenile } \\
\text { population densities with increasing rates of } \\
\text { NVS; this reduction was not sustained to the } \\
\text { end of the growing season. Higher rates did } \\
\text { result in an increase in cotton yields. }\end{array}$ \\
\hline MD & $25,50,75,100$ & M. incognita & Microplot & Incorporated & Loamy sand & $\begin{array}{l}\text { A } 1 \text {-year decrease in } M \text {. incognita population } \\
\text { densities at NVS rates }>75 \text { t/ha. This reduction } \\
\text { was not sustained during subsequent years. }\end{array}$ \\
\hline MI & 10 and 40 & M. hapla & Greenhouse & Incorporated & Sandy loam & $\begin{array}{l}\text { Both rates reduced population densities of } \\
M . \text { hapla, with the higher NVS rate being } \\
\text { more effective. }\end{array}$ \\
\hline FL & $5,10,15$ & M. incognita & Microplot & Incorporated & Loamy sand & $\begin{array}{l}\text { Population densities were suppressed by NVS } \\
\text { at } 36 \text { days; however, this effect disappeared } \\
\text { by } 67 \text { days. }\end{array}$ \\
\hline
\end{tabular}

densities, soil and plant samples at harvest to determine juvenile and egg population densities, and soybean yield. The number of cysts per root system was lower $(P<$ 0.5 ) on the $H$. glycines-resistant cultivar than the $H$. glycines-susceptible cultivar, and NVS had no impact on these data. Harvest $H$. glycines juvenile and egg population densities were numerically higher following NVS treatment. Yield of the $H$. glycines-resistant cultivar increased linearly with regard to NVS application rate $(P$ $<0.05)$. Similar trends were observed during both years. A microplot experiment to evaluate NVS for $H$. glycines suppression was also conducted in North Carolina (H. glycines-resistant and -susceptible cultivars combined with the same NVS rates broadcast-applied) (16) (Table 3). The soil type was a Fuquay sand $(91 \%$ sand, $6 \%$ silt, $3 \%$ clay, $<1 \%$ organic matter). Preplant, midseason, and harvest soil samples were collected to determine H. glycines juvenile and cyst population densities. NVS had no apparent impact on $H$. glycines midseason population densities, and in fact there was an increase in harvest $H$. glycines population densities related to NVS application.

In 2005, higher rates of NVS (13, 27, or 40 dry $\mathrm{t} / \mathrm{ha}$ ) were incorporated into a Norfolk sandy loam naturally infested with $H$. glycines in North Carolina (S. R. Koenning, unpublished data) (Table 3). In a split-plot design, $H$. glycines-resistant and -susceptible soybean cultivars were planted as main plots and NVS rates were

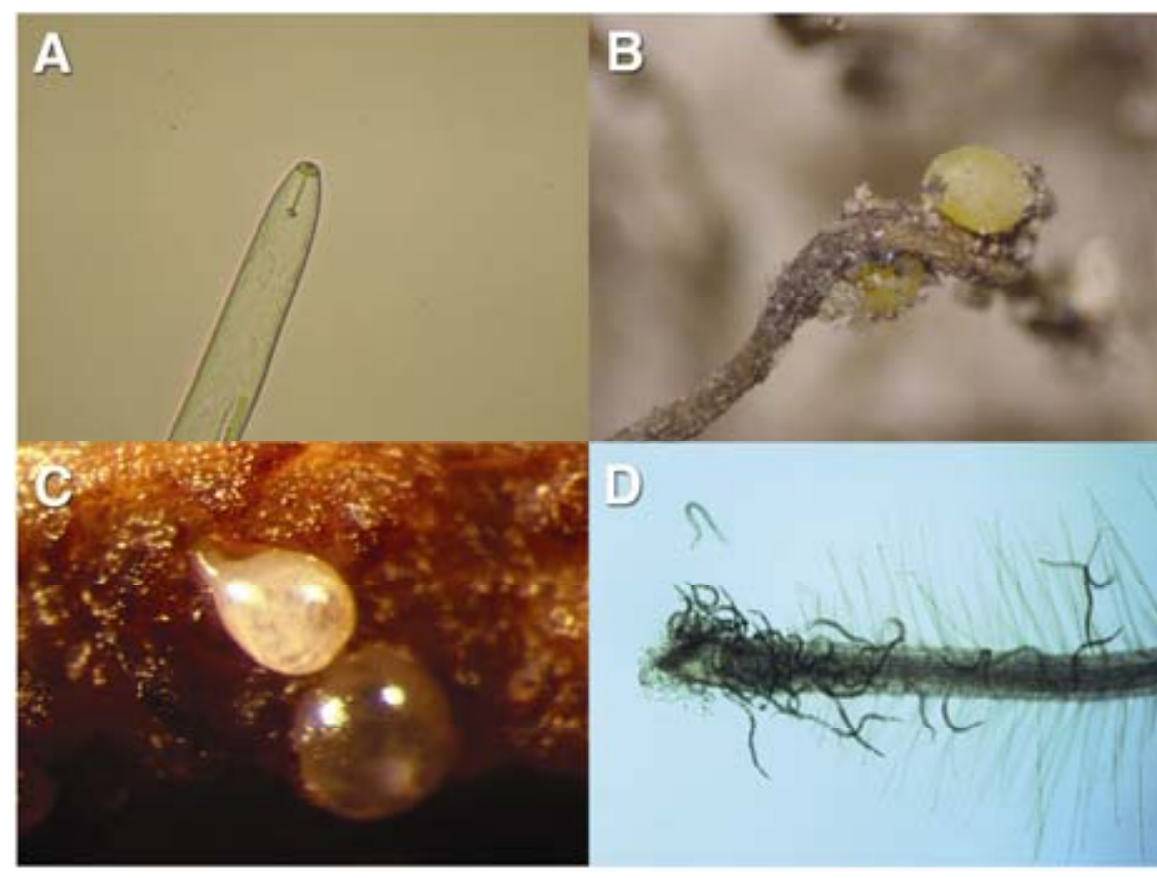

Fig. 3. Plant-parasitic nematodes cause nearly $\$ 10$ billion in crop losses per year in the United States (37). A, Heterodera glycines juvenile; B, H. glycines cysts containing hundreds of nematode eggs; C, Meloidogyne sp. female; and D, Meloidogyne sp. juveniles surrounding a root tip (photos of Meloidogyne sp. with permission from MacTode, Blacksburg, VA).

subplots. Additional treatments included: aldicarb (Temik $15 \mathrm{G}$ at $1.18 \mathrm{~kg}$ a.i./ha) applied in the furrow and a no NVS control. H. glycines population densities were monitored during the season, and soybean yield was determined. Whereas there were no significant differences $(P>0.05)$ in $H$. glycines population densities among treatments, there was a consistent nonsignificant decrease in $H$. glycines harvest egg population densities with increasing rates of NVS regardless of cultivar. The highest 
rate of NVS tested (40 dry t/ha) resulted in an increase in $H$. glycines-susceptible soybean yield compared with those measured at the lower NVS rates, and was not different from yield in the aldicarb-treated plots.

In Michigan, the effects of $0,0.5$, or 2 dry $\mathrm{g}$ of NVS per $100 \mathrm{~cm}^{3}$ (equivalent to 10 and 40 dry t/ha) on three $H$. glycines populations, GN 1, GN 2, and GN 3, classified as HG type 2, HG type 1.2, and HG type 0 , respectively (30), were examined in three greenhouse experiments with glyphosate-tolerant soybean (DSR-221) $(26,27)$ (Table 3). Whereas the responses of the three $H$. glycines populations to NVS treatment varied by experiment, the overall numbers of preadult stages and cysts generally decreased with increasing levels of NVS in all experiments.

\section{Effects of N-Viro Soil on Root-Knot Nematodes}

Root-knot nematodes, Meloidogyne spp. (Fig. 3C and D), were reported as the most destructive nematodes in a global survey (37). Meloidogyne spp. are known parasites of more than 3,000 host plants, and individual species often have wide host ranges. Unlike the situation with $H$. glycines, plant resistance to $M$. incognita is not widespread. The situation is similar for M. hapla (the northern root-knot nematode), a major pest of vegetables in temperate climates. In addition to a lack of usable resistance, nematicides traditionally used to control this group of nematodes are either being phased out or have already been banned (43).

Microplot experiments were conducted with M. incognita on cotton during 2003 and 2004 in North Carolina (S. R. Koenning, unpublished data) (Table 3). Microplots contained a Fuquay sand previously infested with $M$. incognita. Preplant juvenile population densities were determined prior to NVS application. Four rates of NVS $(0,7,13$, and 20 dry t/ha) were broadcast on the soil surface. Midseason and harvest $M$. incognita juvenile population densities were determined, as was cotton yield. NVS effected a linear reduction $(P<0.05)$ in midseason $M$. incognita juvenile population densities, but this reduction was not sustained; harvest population densities were unaffected. There was an increase $(P<0.05)$ in seed cotton yields with increasing rates of NVS during both years.

Microplot experiments in Maryland evaluated the effect of increasing rates of NVS $(0,25,50,75$, and 100 dry $\mathrm{t} / \mathrm{ha})$ on $M$. incognita in soybean (53) (Table 3). The soil type was a Norfolk A loamy sand (87\% sand, $8 \%$ silt, $5 \%$ clay, $<1 \%$ organic matter). NVS was incorporated to a depth of $15 \mathrm{~cm}$, and $M$. incognita population densities (juveniles and eggs) and soil $\mathrm{pH}$ were monitored over a 3-year period. During year 1 , increasing rates of NVS resulted in greater soil solution $\mathrm{pH}$ and degrees of $M$. incognita $\mathrm{J} 2$ and egg suppression (Fig. 5). While soil solution

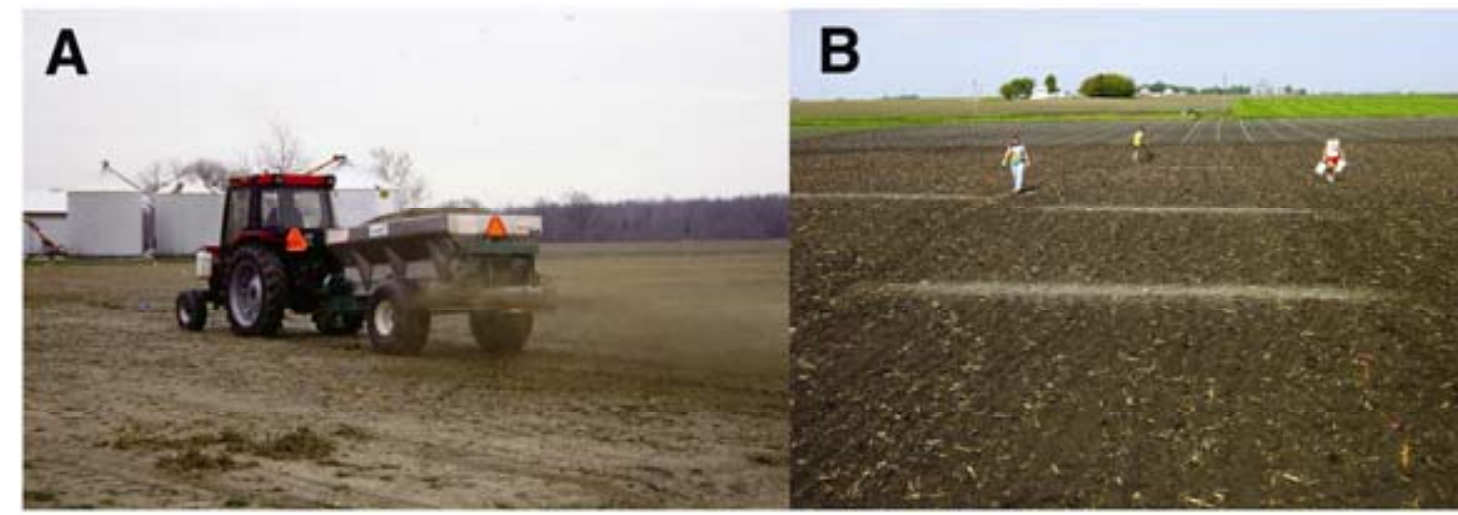

Fig. 4. A, Mechanical application of N-Viro Soil (NVS) in Ontario, Canada (photo courtesy of Tom Welacky, Agriculture and Agri-Food Canada), and B, banded application of 5 dry t/ha NVS to field plots in lowa.

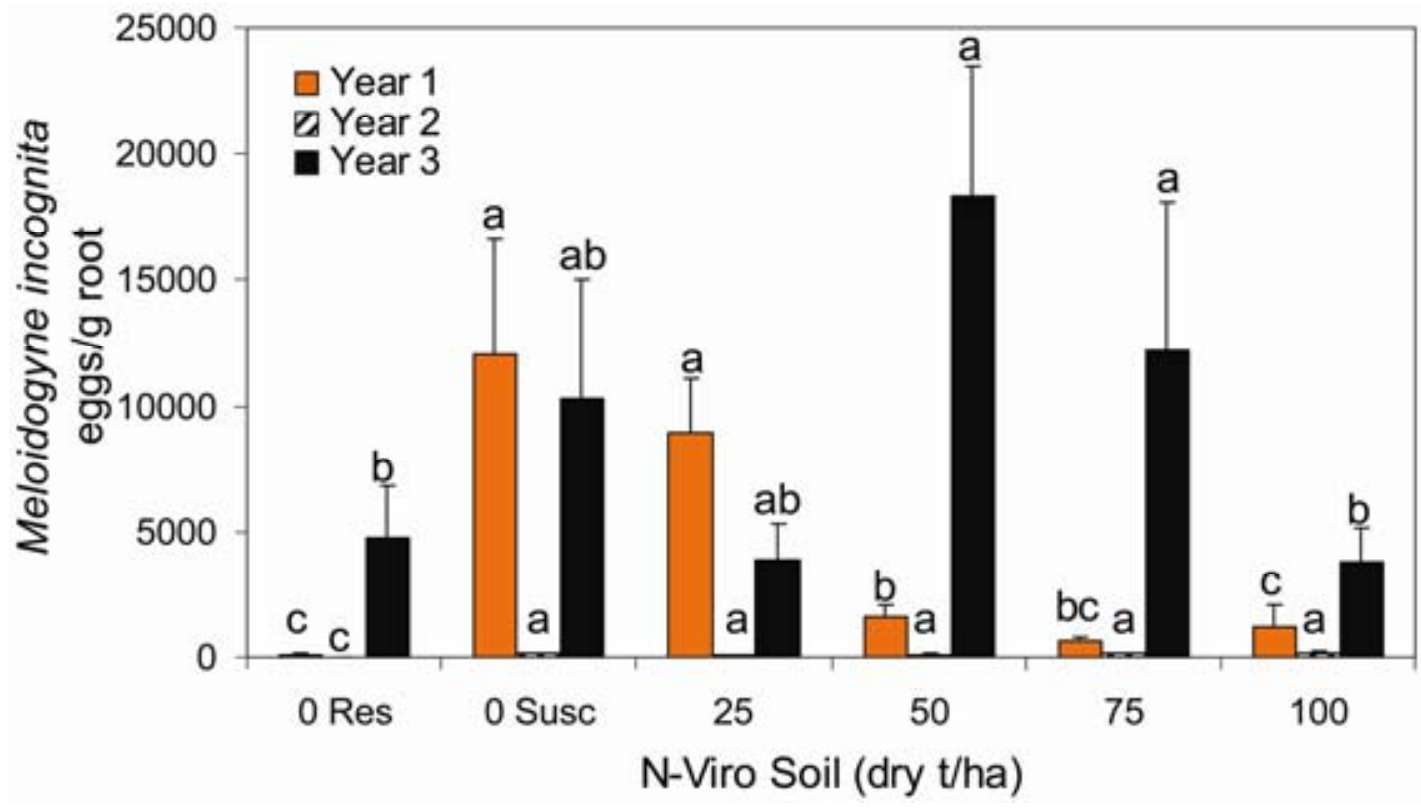

Fig. 5. Meloidogyne incognita egg population densities after incorporation of N-Viro Soil at different rates over time (with permission from Brill Academic Publishers, Boston, MA) (53). Nonamended resistant (res) and susceptible (susc) cultivar controls were included. Bars within years with the same letter are not significantly different according to Tukey's HSD test $(P \leq 0.001)$. 
$\mathrm{pH}$ remained higher in NVS-amended plots during years 2 and 3, M. incognita juvenile and egg population densities were not consistently lower at the higher NVS rates.

Microplot experiments in Florida evaluated the effect of various rates of NVS $(0$, 5,10 , and 15 dry $\mathrm{t} / \mathrm{ha}$ ) on $M$. incognita in tomato (1) (Table 3). The soil type was a Krome very gravelly loam with a soil $\mathrm{pH}$ of 7.6 , texture of about $33 \%$ soil $(<2 \mathrm{~mm})$, $67 \%$ pebbles $(>2 \mathrm{~mm})$, and $<2 \%$ organic matter. NVS was incorporated to a depth of $15 \mathrm{~cm}$, and $M$. incognita population densities (juveniles and eggs) were monitored. The study showed that nematode population densities were reduced by NVS at 36 days, but this effect disappeared by 69 days, when nematode population densities increased in treated plots. However, tomatoes treated with NVS produced more biomass.

Greenhouse studies in Michigan were conducted with a steam-sterilized sandy loam ( $87 \%$ sand, $8 \%$ silt, $5 \%$ clay) to test the response to NVS of different populations of M. hapla grown in tomato (Lycopersicon esculentum) cv. Rutgers (25) (Table 3). Populations of M. hapla from loamy sand, sandy, silt loam, and muck soils with $\mathrm{pHs}$ of $7.2,6.6,7.4$, and 6.3 , respectively, at 0 or 600 eggs per $100 \mathrm{~cm}^{3}$ soil, were tested. These populations came from selected Michigan nursery and vegetable production systems within a radius of about $20 \mathrm{~km}$ and had shown differences in their reproductive potential. When treated with $0,0.5$, or $2 \mathrm{~g}$ of dry NVS per $100 \mathrm{~cm}^{3}$ of soil (equivalent to approximately 10 and 40 dry t/ha), both doses of NVS had significant effects on population densities of all M. hapla populations compared with the controls; the high dose was more suppressive than the low dose (Fig. 6). This suggested that NVS may be effective against these field populations.

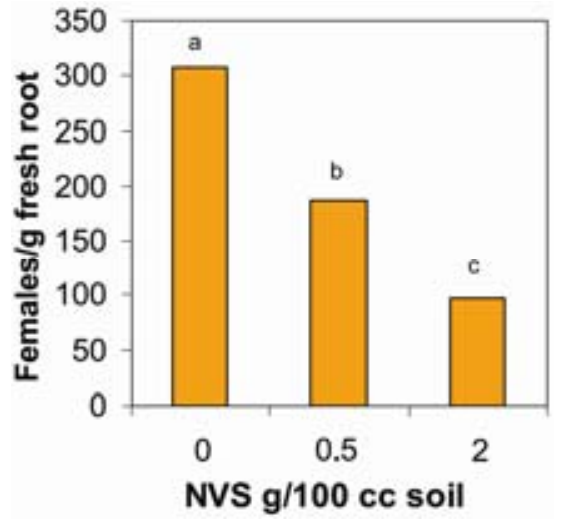

Fig. 6. Effect of $0,0.5$, and $2 \mathrm{~g}$ of dry $\mathrm{N}$ Viro Soil (NVS) per $100 \mathrm{~cm}^{3}$ of sandy loam soil on the densities of Meloidogyne hapla populations (with permission from Elsevier, Orlando, FL) (25).

\section{Considerations When Using NVS to Control Nematodes}

During 5 years of research evaluating NVS for plant-parasitic nematode management, the only common thread was inconsistency (Table 3). This is not surprising considering the diverse environments in which NVS was tested. Our experiences have led to the conclusion that, for consistent, reliable, and environmentally friendly plant-parasitic nematode management, NVS application will have to be implemented with a deeper understanding of the mechanism(s) responsible for nematode suppression. suppression by NVS. To determine the mode of action of NVS against plant-parasitic nematodes, laboratory experiments were conducted $(52,54)$. NVS was applied to sand at $0.5,1,2$, and $3 \%$ dry wt/wt (equivalent to 10 to 60 dry t/ha) with a nonamended control. $M$. incognita and $H$. glycines mortality and changes in sandassay chemical properties were determined after $24 \mathrm{~h}$. The most important chemical property related to nematode mortality was the high $\mathrm{pH}$ level generated in soil solution after amendment (54). To a lesser extent, the production of $\mathrm{NH}_{3}$ played a role in nematode suppression. In subsequent laboratory experiments, the components of NVS (biosolids and AA) were applied to sand to determine the effects on nematode survival, soil solution $\mathrm{pH}$, and $\mathrm{NH}_{3}$ concentrations (52). Alkaline-stabilization of biosolids was necessary to achieve nematode suppression; nontreated biosolids did not suppress $H$. glycines to the same level as equivalent amounts of NVS. Suppression was attributed to soil solution $\mathrm{pH}$ levels after biosolid amendment, which were never greater than 8.5 , whereas NVS amendment resulted in $\mathrm{pH}$ levels greater than 10.0 at rates of $1 \%$ dry wt/wt or
Proposed mechanism of nematode higher. In the same experiment, there was a weak relationship between the amount of $\mathrm{NH}_{3}$ generated after NVS amendment and $H$. glycines mortality. These laboratory experiments provide evidence to suggest that the $\mathrm{pH}$-mediated transformation of $\mathrm{NH}_{4}{ }^{+}$to $\mathrm{NH}_{3}$ (Fig. 2C) is at least partially responsible for the plant-parasitic nematode suppression achieved after amendment of soil with NVS. The challenge is to understand this chemical reaction and to utilize it in an environmentally responsible manner to achieve nematode suppression.

The toxicity of gaseous $\mathrm{NH}_{3}$ to plantparasitic nematodes and other soilborne pests is well documented $(8,31,34,36$, 40,48). Suppression of plant-parasitic nematodes by $\mathrm{NH}_{3}$ depends on its concentration in soil air and solution, which is determined by several factors including $\mathrm{NH}_{3} / \mathrm{NH}_{4}{ }^{+}$equilibrium. The equilibrium between $\mathrm{NH}_{3}$ and $\mathrm{NH}_{4}{ }^{+}$is dependent on the $\mathrm{pH}$ of soil solution (and temperature), and follows the Henderson-Hasselbalch equation (Fig. 2C). For example, at $\mathrm{pH} 9.5$, approximately half of the $\mathrm{NH}_{3}$ plus $\mathrm{NH}_{4}{ }^{+}$ exists as $\mathrm{NH}_{3}$ at a temperature of $20^{\circ} \mathrm{C}$ (Fig. 7). Despite $\mathrm{NH}_{3}$ toxicity, the use of $\mathrm{NH}_{3}$ for controlling plant-parasitic nematodes has not been accepted commercially (31). Several reasons have been cited, including the dependence of $\mathrm{NH}_{3}$ toxicity on environmental conditions, the large amounts of $\mathrm{NH}_{3} / \mathrm{NH}_{4}{ }^{+}$needed to achieve control, and the frequent phytotoxic effects of high rates on plants. We and others (32) believe that excessive rates of nitrogenous materials have been ineffective in previous research because specific soil $\mathrm{pH}$ values were not present to generate toxic concentrations of $\mathrm{NH}_{3}$ in soil solution. We believe NVS can be used to transiently raise soil $\mathrm{pH}(\geq 10.0)$, which converts most soil $\mathrm{NH}_{4}{ }^{+}$to the active gaseous $\mathrm{NH}_{3}$ form (Figs. 2C and 7). This is a delicate balance,

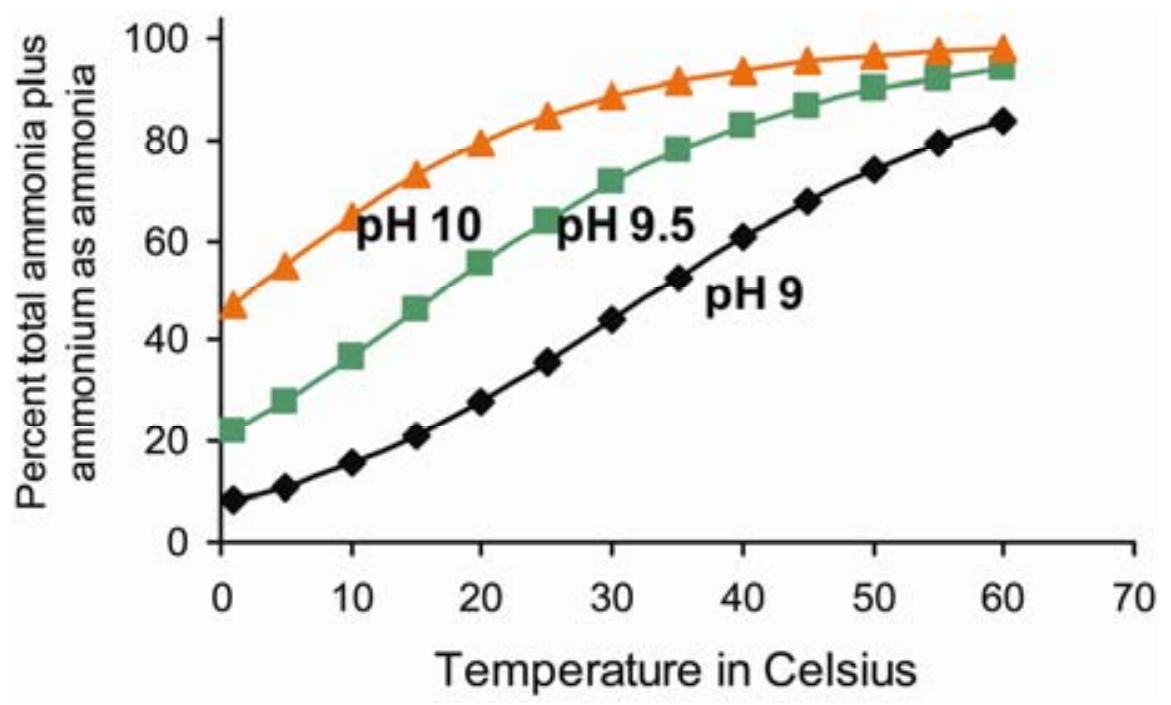

Fig. 7. The equilibrium between ammonium $\left(\mathrm{NH}_{4}{ }^{+}\right)$and ammonia $\left(\mathrm{NH}_{3}\right)$ as influenced by temperature and $\mathrm{pH}$ (with permission from $\mathrm{M}$. Tenuta, University of Manitoba, Winnipeg, MT). 
and care must be taken to minimize negative effects on soil structure and chemistry. We therefore believe that management of plant-parasitic nematodes using NVS should be advocated only in those environments where this chemical reaction $(\mathrm{pH}$ and $\mathrm{NH}_{3}$ ) can be manipulated effectively.

Soil properties. Our field studies were conducted on a range of soil textures, from sand in North Carolina to loam in Iowa and calcareous in Florida, and results were variable across the sites (Table 3 ). In general, we did not observe plant-parasitic nematode suppression in the sandy loam to loam soils of Iowa, and had some nematode suppression, especially when higher rates were applied, when soil textures ranged from sand to loamy sand in North Carolina, Michigan, and Maryland. Previous research provides evidence of why NVS was effective in some soil textures while not in others. Tenuta and Lazarovits (41) identified soil properties associated with the accumulation of $\mathrm{NH}_{3}$. Ammonia toxicity occurred in soils with low rates of nitrification, low levels of cation exchange capacity, and organic carbon contents, but high bulk densities and sand contents. In another study (42), cation exchange reactions involving the adsorption of $\mathrm{NH}_{3}$ and $\mathrm{NH}_{4}{ }^{+}$to soil particles was not a primary determinant of $\mathrm{NH}_{3}$ accumulation, and bulk density only slightly affected $\mathrm{NH}_{3}$ accumulation. The authors concluded that nitrogenous amendments should be applied to soils having low organic carbon and high sand content.

Soils also differ in their $\mathrm{pH}$ buffering capacities, which would influence the ability of NVS to raise soil $\mathrm{pH}$. The initial $\mathrm{pH}$ of NVS is above 12.0, and care should be taken as $\mathrm{pH}$ can adversely affect the behavior of soils and nutrient availability $(10,13,18)$. This means that NVS should be applied only to those soils where $\mathrm{pH}$ can be rapidly returned to normal after promoting the accumulation of $\mathrm{NH}_{3}$ in soil. Candidate soils would include sandy, low organic matter, alkaline soils. If properly managed, $\mathrm{pH}$ recovery in NVSamended soils can be rapid (20). For example, in Florida, 20 dry t/ha of NVS was applied to a Krome gravelly loam (bulk density $1.42 \mathrm{~g} / \mathrm{cm}^{3}, 51 \%$ coarse material, $18 \%$ sand, $65 \%$ inorganic carbon, and $1.5 \%$ organic carbon), initial $\mathrm{pH} 7.9$, and the change in soil solution $\mathrm{pH}$ over time was measured (Y. Li and I. A. Zasada, unpublished data). Immediately after NVS amendment, soil solution $\mathrm{pH}$ was greater than 11.0, but after 10 days the $\mathrm{pH}$ had returned to 8.5 , slightly above the initial $\mathrm{pH}$. While we do not advocate increasing soil $\mathrm{pH}$ to above 11.0, this does provide an example of a soil where nitrogenous amendments in combination with elevated $\mathrm{pH}$ could be implemented for plant-parasitic nematode management.

Environmental conditions. As discussed in a previous section, the generation of concentrations of $\mathrm{NH}_{3}$ toxic to plantparasitic nematodes depends on its concentration in soil air and solution, which is determined by $\mathrm{NH}_{4}{ }^{+}$concentration, $\mathrm{NH}_{3} / \mathrm{NH}_{4}{ }^{+}$equilibrium, soil $\mathrm{pH}$, and the environmental conditions present when nitrogenous amendments are added to soil. It has been shown that external factors need to be taken into consideration when predicting $\mathrm{NH}_{3}$ volatilization following manure application (14). Two environmental conditions to consider are soil temperature and moisture.

Soil temperature was found to explain the largest variability in soil $\mathrm{NH}_{3}$ volatilization (35) (Fig. 7). Ammonia volatilization after urea application was highest after 2 days and corresponded with daily maximum temperatures (9). The volatilization of $\mathrm{NH}_{3}$ increased $18 \%$ as the temperature of incubation was increased $16^{\circ} \mathrm{C}$, from 4 to $20^{\circ} \mathrm{C}(50)$. Also, whereas a low temperature favors a high equilibrium yield of $\mathrm{NH}_{3}$, it dictates that a long time will be required to obtain the yield. Because higher soil temperatures promote the rapid conversion of $\mathrm{NH}_{4}^{+}$to $\mathrm{NH}_{3}$, to obtain plant-parasitic nematode control and to minimize excess additions of $\mathrm{N}$ to soil, NVS application should occur when soil temperatures are warm. This timing may or may not be realistic depending upon the production system in which this technology would be employed.

Moisture also influences the retention and loss of $\mathrm{NH}_{3}$ from soil. Volatilization has been shown to increase with decreasing soil water content $(5,12,19,35)$. Adding water to soil after the application of urea decreased $\mathrm{NH}_{3}$ losses by $15 \%$ (6). Similarly, Liu et al. (19) reported that $\mathrm{NH}_{3}$ volatilization rate at $20 \%$ field moisture capacity (FC) was twoto three-fold greater than that at $80 \%$ FC for various forms of $\mathrm{N}$ fertilizers applied to four Washington and Florida soils. Heavy rainfall was a major determinant in a model predicting the transfer of $\mathrm{NH}_{3}$ across the soil/air interface (35). It is more difficult to understand the role of moisture and how it relates to $\mathrm{NH}_{3}$ exposure to plant-parasitic nematodes. When soils were amended with bone meal, $\mathrm{NH}_{3}$ toxicity occurred in those soils with low moisture levels (42). In another study (41), soil moisture only slightly affected the accumulation of $\mathrm{NH}_{3}$ in an alkaline loam soil. While low soil moisture increases $\mathrm{NH}_{3}$ volatility, it stands to reason that the concentration of $\mathrm{NH}_{3}$ in solution would be less dilute, therefore increasing the concentration to which nematodes are exposed. Conversely, although high soil moisture minimizes volatility, it also makes the concentration of $\mathrm{NH}_{3}$ in solution more dilute. The exact soil moisture necessary to optimize the use of NVS, alone or in combination with another $\mathrm{N}$ source, is not clear but will vary from soil to soil.

Application rates. The rates of NVS evaluated in our experiments ranged from
6 to 100 dry t/ha (Table 3 ). As a limestone substitute, NVS would typically be applied at a rate of 10 t/ha dry weight every 2 to 4 years, depending on location. The lower rates used in our field studies did not consistently control plant-parasitic nematodes, so clearly a liming rate of NVS would not be effective. Higher rates were needed to achieve plant-parasitic nematode control, but these higher rates also resulted in dramatic increases in soil $\mathrm{pH}$, a practice that is not encouraged because of negative effects on soil nutrient availability and structure. The goal is to apply a rate of NVS that facilitates a transient increase in $\mathrm{pH}$ and the production of toxic concentrations of $\mathrm{NH}_{3}$ in soil solution. Because of the way NVS is produced, $\mathrm{N}$ exists almost entirely as organic $\mathrm{N}$. To achieve toxic concentrations of $\mathrm{NH}_{3}$, it may be necessary to add additional nitrogen in the form of fertilizers or nitrogenous amendments. Achieving nematode management through the manipulation of the nitrogen cycle is a fine balancing act and is advocated only in environments where this can be achieved in an environmentally responsible manner. It is important to point out that the source of ammoniacal-N (e.g., chicken litter, urea, bone meal) needs to be labile in order to take advantage of the rapid increase in $\mathrm{pH}$ that occurs after the addition of NVS to soil.

Product variability. To determine the ability to implement NVS for plant-parasitic nematode management across geographic locations, NVS from different processing facilities were tested against $H$. glycines (52). Of the five NVS sources tested (at rates equivalent to approximately $60 \mathrm{dry}$ t/ha), four of them reduced H. glycines juvenile abundance more than $95 \%$; a single source resulted in $56 \%$ reduction. NVS manufactured from different source materials and formulations have markedly different properties. Differences occur in the AA used, treatment of biosolids prior to stabilization (primary [3 to $7 \%$ solids] versus secondary [0.5 to $2 \%$ solids]), and the materials present in the wastewaters (28).

One of the most important considerations, regardless of NVS source, is the age and $\mathrm{pH}$ of the product. For NVS to be used as a vehicle to transiently increase soil $\mathrm{pH}$ to promote the production of $\mathrm{NH}_{3}$, the initial $\mathrm{pH}$ of the NVS must be greater than 12.0. This will require that a relatively young batch (1 to 2 months) of NVS be used for plant-parasitic nematode management. Despite the differences in NVS composition from different locations, our research demonstrated that NVS produced from a diversity of by-products has the potential to be implemented on a wide geographic scale for plant-parasitic nematode management.

Application methods. In these studies, NVS was applied as a surface broadcast application, broadcast then incorporated 
application, and banded application (Table 3). We do not have a comparison of how higher rates of NVS, where we observed nematode mortality, performed when applied to the surface versus incorporated, but previous research indicates that narrow-banded application of manure significantly reduced $\mathrm{NH}_{3}$ volatilization compared with broadcast application (14). The mean cumulative volatilization for broadcast application was $77 \%$ of the total ammoniacal-N applied, whereas it was $20 \%$ for narrow-banded application. These results indicate that $\mathrm{NH}_{3}$ losses can be minimized, which would also increase exposure concentrations of $\mathrm{NH}_{3}$ to plantparasitic nematodes in soil.

Another application method that would minimize loss of $\mathrm{NH}_{3}$ to the environment and promote the production of $\mathrm{NH}_{3}$ is tarping of the soil after application. Because temperature influences the equilibrium between $\mathrm{NH}_{4}{ }^{+}$and $\mathrm{NH}_{3}$ (Fig. 7) and because tarping increases soil temperature in some environments (39), tarping should increase the amount of $\mathrm{NH}_{3}$. Sealing treated soil in plastic bags reduced the amount of $\mathrm{NH}_{4} \mathrm{OH}$ required to kill $M$. javanica (31). The use of tarps after the application of NVS to achieve nematode suppression would be most applicable to smaller acreage or higher value crops.

\section{Future of Biosolid Use for Nematode Management}

Many of the trends associated with land application of biosolids are likely to continue (3). Land application will increase, and increasing costs will discourage landfilling and incineration of biosolids. Coupled with this will be the increased production of class A, exceptional quality biosolids requiring fewer reporting requirements because they contain lower amounts of heavy metals and undesirable chemical and biological constituents. NVS is one of these products.

Public perception is the key to the acceptance of biosolids for new uses (28). Some food processors currently restrict the use of biosolids on agricultural products. Extensive public education and awareness programs need to be implemented for biosolids to be viewed as a resource rather than a disposal problem $(4,28)$. Regardless of where an individual, company, university, or federal agency stands regarding the controversial use of biosolids on agricultural lands (38), the inescapable question still exists: how will we as a society manage our waste? With a growing population and increasing amounts of biosolids, it is essential to implement recovery options for biosolids and ultimately tactics for their disposal that are safe for humans and the environment, and are economically viable.

From a plant-parasitic nematode management perspective, the two largest obstacles for the implementation of this technology are its inconsistent performance and the acceptance of using $\mathrm{NH}_{3}$ in combination with elevated soil $\mathrm{pH}$ as a soil disinfectant. Our results indicate that if NVS is to be applied alone for plant-parasitic nematode management, then the rate will have to be greater than 50 dry $t / h a$. This is not economically or environmentally acceptable. The amount of NVS, when applied alone, required for nematode suppression results in undesirable soil $\mathrm{pH}$ levels, which could lead to nutrient management problems. From an economic perspective, it may not be feasible to apply more than about 10 dry t/ha/year. The primary cost in utilizing NVS is the cost of transportation and spreading of this amount of material.

However, there is solid evidence from the research presented here and by others $(31,32,40)$ that the mechanism responsible for nematode suppression by NVS, the production of $\mathrm{NH}_{3}$ in combination with elevated $\mathrm{pH}$, may be possible to achieve in some environments. In this case, the rate of NVS would be reduced and used to achieve a transient increase in soil $\mathrm{pH}$ to facilitate the production of $\mathrm{NH}_{3}$. The environments where this technology could be employed will include only those soils where this chemical reaction can be maximized (sandy, low organic matter, or alkaline soils) and high value or small acreage crops where soil moisture and temperature can be manipulated by tarping or other tactics.

\section{Literature Cited}

1. Amann, N. 2006. Using soil amendments to control soil nematodes and improve soil fertility and tomato growth in a micro-plot experiment. M.S. thesis. University of Applied Sciences in Osnabrück, Germany.

2. Barbosa, G. M. de C., Mendes, M. L., TavaresFilho, J., Rodriguez, P. B. N., and Vizoni, E. 2004. Effect of sewage sludge compost on Meloidogyne javanica on tomato. Nematropica 34:13-21.

3. Basta, N. T. 2000. Examples and case studies of beneficial reuse of municipal by-products. In: Land Application of Agricultural, Industrial, and Municipal By-products. J. F. Power, ed. Book Series No. 6. Soil Science Society of America, Madison, WI.

4. Beecher, N., and Goldstein, N. 2005. Public perceptions of biosolids recycling. Biocycle 46:34-56.

5. Black, A. S., Sherlock, R. R., and Smith, N. P. 1987. Effect of timing of simulated rainfall on ammonia volatilization from urea, applied to soil of varying moisture content. J. Soil Sci. 38:679-687.

6. Burnham, J. C., Hatfield, N., Bennett, G. F., and Logan, T. J. 1992. Use of kiln dust and quicklime for effective municipal biosolids pasteurization and stabilization with the $\mathrm{N}$ Viro Soil process. Pages 128-141 in: Innovations and Uses for Lime. D. D. Walker, T. B. Hardy, D. C. Hoffman, and D. D. Stanley, eds. ASTM STP 1135. Philadelphia, PA.

7. Castagnone-Sereno, P., and Kermarrec, A. 1991. Invasion of tomato roots and reproduction of Meloidogyne incognita as affected by raw sewage sludge. J. Nematol. 23:724-728.

8. Chun, D., and Lockwood, L. 1985. Reductions of Pythium ultimum, Thielaviopsis basicola, and Macrophomina phaseolina populations in soil associated with ammonia generated from urea. Plant Dis. 69:154-158.

9. Clay, D. E., Malzer, G. L., and Anderson, J. L. 1990. Ammonia volatilization from urea as influenced by soil temperature, soil water content and nitrification and hydrolysis inhibitors. Soil Sci. Soc. Am. J. 54:263-266.

10. Goldberg, S., and Forster, H. S. 1990. Flocculation of reference clays and arid-zone soil clays. Soil Sci. Soc. Am. J. 54:714-718.

11. Goldstein, N. 2000. The state of biosolids in America. BioCycle 41:50-56.

12. Habicht, W. A., Jr. 1975. The nematicidal effects of varied rates of raw and composted sewage sludge as soil organic amendments on a rootknot nematode. Plant Dis. Rep. 59:631-634.

13. Hesterberg, D., and Page, A. L. 1990. Critical coagulation concentration of sodium and potassium illite as affected by $\mathrm{pH}$. Soil Sci. Soc. Am. J. 54:735-739.

14. Huijsmans, J. F. M., Hol, J. M. G., and Hendriks, M. M. W. B. 2001. Effect of application technique, manure characteristics, weather and field conditions on ammonia volatilization from manure applied to grasslands. Wageningen J. Life Sci. 49:323-342.

15. Koenning, S. R. 2004. Resistance of soybean cultivars to field populations of Heterodera glycines in North Carolina. Plant Dis. 88:942950 .

16. Koenning, S. R. 2004. Impact of N-Viro soil on Heterodera glycines with resistant and susceptible cultivars. (Abstr.) J. Nematol. 36:327.

17. Koenning, S. R., Overstreet, C., Noling, J. W., Donald, P. A., Becker, J. O., and Fortnum, B. A. 1999. Survey of crop losses in response to phytoparasitic nematodes in the United States for 1994. Suppl. J. Nematol. 31:587-618.

18. Lebron, I., and Suarez, D. L. 1992. Variations in soil stability within and among soil types. Soil Sci. Soc. Am. J. 56:1412-1421.

19. Liu, G. D., Li, Y. C., and Alva, A. 2007. Moisture quotients for ammonia volatilization from four soils in potato production regions. Water Air Soil Pollution 183:115-127.

20. Logan, T. J. 1993. Alkalinity and liming value of N-Viro Soil materials. Proc. 66 Annu. Conf. Water Environ. Fed., Alexandria, VA.

21. Logan, T. J., and Burnham, J. C. 1995. The alkaline stabilization with accelerated drying process (N-Viro): An advanced technology to convert sewage sludge into a soil product. Pages 209-223 in: Agricultural Utilization of Urban and Industrial By-Products. D. L. Karlen, ed. Am. Soc. Agron. Spec. Pub. No. 58.

22. Logan, T. J., Lindsay, B. J., and Titko, S. 1997. Characteristics and standards for processed biosolids in the manufacture and marketing of horticultural fertilizers and soil blends. Pages 63-71 in: Agricultural Uses of By-Products and Wastes. J. E. Rechcigl and H. C. MacKinnon, eds. American Chemical Society, Washington, DC.

23. Mannion, C. M., Schaffer, B., Ozores-Hampton, M., Bryan, H. H., and McSorley, R. 1994. Nematode population dynamics in municipal solid waste-amended soil during tomato and squash cultivation. Nematropica 24:17-24.

24. McSorley, R., Stansly, P. A., Noling, J. W., Obreza, T. A., and Conner, J. M. 1997. Impact of organic soil amendments and fumigation on plant-parasitic nematodes in a southwest Florida vegetable field. Nematropica 27:181-189.

25. Melakeberhan, H., Mennan, S., Chen, S., Darby, B., and Dudek, T. Integrated biological approaches to understanding and managing Meloidogyne hapla populations' parasitic variability. Crop Prot. In press.

26. Melakeberhan, H., and Noel, G. R. 2004. Response of selected Heterodera glycines populations to N-Viro soil treatment. (Abstr.) J. Nematol. 36:333-334.

27. Melakeberhan, H., and Noel, G. R. 2006. Effects of biosolid soil amendment on Het- 


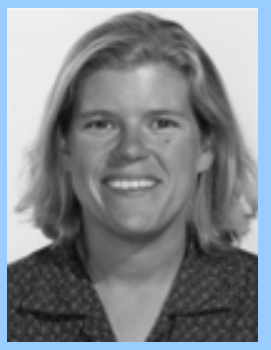

Inga Zasada

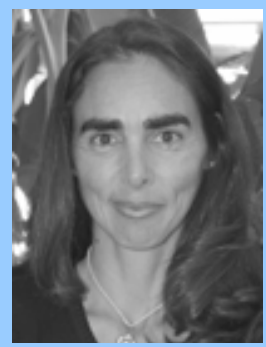

Felicitas Avendano

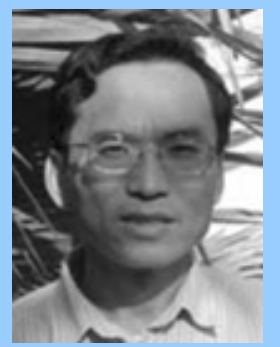

Yuncong Li

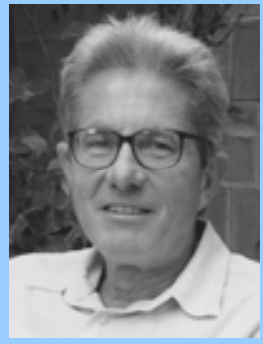

Terry Logan

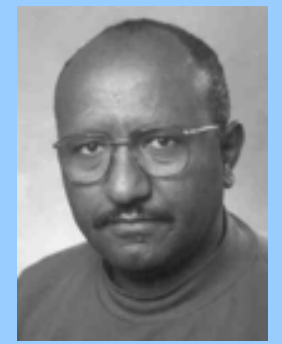

Haddis Melakeberhan

Dr. Inga Zasada is a research plant pathologist for the USDA-ARS Nematology Laboratory, Beltsville, MD. She received her B.S. in Crop Science from Oregon State University in 1992, an M.S. in crop science from North Carolina State University in 2003, and a Ph.D. in plant pathology from the University of California, Davis. In 2003, she was hired to specifically work on the congressionally mandated project " $\mathrm{N}$ Viro Soil for plant-parasitic nematode management". Current research interests include plant-parasitic nematode management with organic and inorganic amendments.

Dr. Felicitas Avendano is a postdoctoral research associate in the Department of Plant Pathology at lowa State University. She received a B.S./M.S. in biology-parasitology from Universidad Nacional de Mar del Plata, Argentina, and a Ph.D. in entomology/nematology from Michigan State University. Her research interests focus on plant-pest interactions that involve parasitic nematodes. She is currently studying the joint effect that the soybean cyst nematode and the soybean aphid may have on the soybean plant and on each other.

Dr. Yuncong $\mathrm{Li}$ received a B.S. in soil science from Shandong Agricultural University, China, an M.S. in soil chemistry/agronomy from the University of Georgia, and a $\mathrm{Ph} . \mathrm{D}$. in environmental science from University of Maryland. He was a postdoctoral research associate for three years at the University of Florida Indian River Research and Education Center in Ft. Pierce, FL, where his research focused on nutrient management for citrus. His current appointment is as an associate professor and extension specialist at University of Florida Tropical Research and Education Center in Homestead, FL. His research areas are developing management practices to improve nutrient use efficiency, plant nutrition, and water quality; characterizing nutrient cycling in calcareous soils; determining impacts of agriculture on south Florida's natural ecosystems; and conducting research on water quality monitoring, assessment, and remediation.

Dr. Terry Logan is president of Logan Environmental Inc., which provides consulting services in biomineral by-product management to municipalities, industry, and agriculture. Dr. Logan holds B.S., M.S., and Ph.D. degrees in soil science. From 1999 to 2004, he was president and then CEO of N-Viro International Corporation. Prior to 1999, he was a soil chemist in the School of Natural Resources at The Ohio State University, where he held the rank of professor. Dr. Logan's research has been in the general area of agricultural environmental quality, with specialization in water quality and beneficial use of biosolids and animal manure on agricultural land. He is a Fellow of the Soil Science Society of America, American Society of Agronomy, and the American Association for the Advancement of Science.

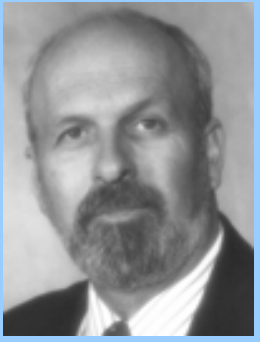

Stephen Koenning

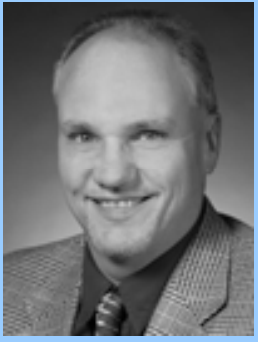

Greg Tylka
Dr. Haddis Melakeberhan, a native of Eritrea, is associate professor of nematology at Michigan State University (MSU). $\mathrm{He}$ received his agriculture and crop protection diplomas from Ambo Institute of Agriculture, Ethiopia, and Harper Adams Agricultural College, England, respectively. His M.Sc. and Ph.D. in nematology are from Imperial College, University of London, England, and Simon Fraser University, Canada, respectively. Focusing on nutrient relations and nematodes of destructive (host cells killed), adaptive (cells modified), and neoplastic (cells modified and undergo new growth) feeding behaviors, Dr. Melakeberhan's long-term research program goal is to develop sustainable management strategies through understanding host-nematode interactions from the organismal to the ecosystem level. Using Pratylenchus (root-lesion), Heterodera (soybean cyst), and Meloidogyne (root-knot) as models, areas of specific focus include understanding the effects of production systems on nematode adaptation and parasitic variability and assessing the agroecological efficiency of management strategies. The program strives to maintain a loop linking basic and applied nematology with plant and soil science disciplines.

Dr. Stephen Koenning received a B.S. in biology and an M.S. in plant pathology from the University of Arizona. He received a Ph.D. from North Carolina State University in 1984 in the Department of Plant Pathology. Postdoctoral research included two years at the University of Missouri Delta Center in Portageville, MO, working on the soybean cyst nematode. His current appointment is as a research assistant professor and extension specialist at North Carolina State University with extension responsibilities for all diseases of corn, cotton, and soybean. He received the Best Economic Nematology Paper Award in 1986, and the Novartis Award for Excellence in Research in 2000 from the Society of Nematologists. Current research interests include management of plant-parasitic nematodes in conventional and sustainable agricultural systems.

Greg Tylka is a professor of plant pathology at lowa State University. He obtained his B.S. and M.S. degrees in biology at California University of Pennsylvania and his Ph.D. in plant pathology from the University of Georgia. At lowa State University since February 1990, Tylka has responsibilities for applied research and extension education relating to plantparasitic nematodes. Most of his work has been with the soybean cyst nematode. Recently, his research has focused on studying the effects of soybean production practices and resistant varieties on soybean cyst nematode population densities and soybean yields. Additionally, his research group is investigating interactions of the soybean cyst nematode with the soybean brown stem rot pathogen, Cadophora gregata, and with the soybean aphid, Aphis glycines. 
erodera glycines populations. J. Nematol. 38:349-353.

28. Muchovej, R. M. C., and Pacovsky, R. S. 1997. Future directions of by-products and wastes in agriculture. Pages 1-21 in: Agricultural Uses of By-Products and Wastes. J. E. Rechcigl and $\mathrm{H}$. C. MacKinnon, eds. American Chemical Society, Washington, DC.

29. Niblack, T. L. 2005. Soybean cyst nematode management reconsidered. Plant Dis. 89:10201026.

30. Niblack, T. L., Arelli, P. R., Noel, G. R., Opperman, C. H., Orf, J. H., Schmitt, D. P., Shanon, J. G., and Tylka, G. L. 2002. A revised classification scheme for genetically diverse populations of Heterodera glycines. J. Nematol. $34: 279-288$.

31. Oka, Y., and Pivonia, S. 2002. Use of ammonia-releasing compounds for control of the root-knot nematode Meloidogyne javanica. Nematology 4:65-61.

32. Oka, Y., Tkachi, N., Shuker, S., Rosenberg, R., Suriano, S., and Fine, P. 2006. Laboratory studies on the enhancement of nematicidal activity of ammonia-releasing fertlisers by alkaline amendments. Nematology 8:335-346.

33. Rampton, S. 1998. Let them eat nutri-cake: Merriam-Webster thinks our "biosolids" don't stink. Harpers 297:48-50.

34. Rodríguez-Kábana, R., Shelby, R. A., King, P. S., and Pope, M. H. 1982. Combinations of anhydrous ammonia and 1,3-dichloropropenes for control of root-knot nematodes in soybeans. Nematropica 12:61-69.

35. Roelle, P. A., and Aneja, V. P. 2002. Characterization of ammonia emissions from soils in the upper coastal plain, North Carolina. Atmosphere. Environ. 36:1087-1097.
36. Rush, C. M., and Lyda, S. D. 1982. Effects of anhydrous ammonia on mycelium and sclerotia of Phymatotrichum omnivorum. Phytopathology 72:1085-1089.

37. Sasser, J. N., and Freckman, D. W. 1987. A world perspective on nematology: The role of the society. Pages 7-14 in: Vistas on Nematology. J. A. Veech and D. W. Dickson, eds. Society of Nematologists, Hyattsville, MD.

38. Snyder, C. 2005. The dirty work of promoting "recycling" of America's sewage sludge. Int. J. Occup. Environ. Health, 11:415-427.

39. Stapleton, J. J. 2000. Soil solarization in various agricultural production systems. Crop Prot. 19:837-841.

40. Tenuta, M., and Lazarovits, G. 2002. Ammonia and nitrous acid from nitrogenous amendments kill the microsclerotia of Verticillium dahliae. Phytopathology 92:255-264.

41. Tenuta, M., and Lazarovits, G. 2002. Identification of specific soil properties that affect the accumulation and toxicity of ammonia to Verticillium dahliae. Can. J. Plant Pathol. 24:219229.

42. Tenuta, M., and Lazarovits, G. 2003. Soil properties associated with the variable effectiveness of meat and bone meal to kill microsclerotia of Verticillium dahliae. App. Soil Ecol. 25:219-236.

43. Thomason, I. J. 1987. Challenges facing nematology: Environmental risks with nematicides and the need for new approaches. Pages 469476 in: Vistas on Nematology. J. A. Veech and D. W. Dickson, eds. Society of Nematologists, Hyattsville, MD

44. U.S. Environmental Protection Agency. 1977. Clean water act. Available on line at http://www.epa.gov/r5water/cwa.htm.
45. U.S. Environmental Protection Agency. 1993. Standards for the use or disposal of sewage biosolids, 40 CFR part 503. Federal Register. 58:9387-9404.

46. U.S. Environmental Protection Agency. 1994 A plain English guide to the EPA. Part 503 biosolids rule. EPA/832/R-93/003. Office of Research and Development, Washington, DC.

47. U.S. Environmental Protection Agency. 1999. Biosolids generation, use and disposal in the United States. EPA530-R-99-009. Office of Solid Waste and Emergency Response, Washington, DC.

48. Warren, K. S. 1962. Ammonia toxicity and pH Nature 195:45-49.

49. Welacky, T. W., and Topp, E. 2001. Control of soybean cyst nematode Heterodera glycines with lime-stabilized municipal biosolids. (Abstr.) Phytopathology 91:S145.

50. Whitehead, D. C. 1991. Effects of some environmental factors on ammonia volatilization from simulated livestock urine applied to soil. Biol. Fert. Soils 11:279-284.

51. Wrather, J. A., Stienstra, W. C., and Koenning, S. R. 2001. Soybean disease loss estimates for the United States from 1996 to 1998. Can. J. Plant Pathol. 23:122-131.

52. Zasada, I. A. 2005. Factors affecting the suppression of Heterodera glycines by N-Viro Soil. J. Nematol. 37:220-225.

53. Zasada, I. A., Rogers, S. T., and Sardanelli, S. 2007. Application of alkaline-stabilized biosolids for Meloidogyne incognita suppression in microplots. Nematology 9:123-129.

54. Zasada, I. A., and Tenuta, M. 2004. Chemicalmediated toxicity of N-Viro Soil to Heterodera glycines and Meloidogyne incognita. J. Nematol. 36:297-302. 